\title{
HBV markers in haemodialysis Brazilian patients: a prospective 12-month follow-up
}

\author{
Regina Célia Moreira ${ }^{1 /+}$, Marta Mitiko Deguti ${ }^{2}$, Marcilio Figueiredo Lemos ${ }^{1}$, Cláudia Patara Saraceni ${ }^{1}$, \\ Isabel Takano Oba', Angela Maria Miranda Spina', Alessandra Stilhano Nascimento-Lima², \\ Jorge Fares ${ }^{3}$, Raymundo Soares Azevedo ${ }^{4}$, Michele Soares Gomes-Gouvêa ${ }^{2}$, Flair José Carrilho², \\ João Renato Rebello Pinho
}

${ }^{1}$ Serviço de Virologia, Instituto Adolfo Lutz, Av. Dr. Arnaldo 355, 01246-902 São Paulo, SP, Brasil ²Departamento de Gastroenterologia (LIM 07) ${ }^{3}$ Centro de Hemodiálise ${ }^{4}$ Departamento de Patologia (LIM 01), Faculdade de Medicina, Universidade de São Paulo, São Paulo, SP, Brasil

The aim of this study was to determine the prevalence and the incidence of hepatitis $B$ virus (HBV) among haemodialysis (HD) subjects and to evaluate whether testing for serological markers at the time of admission is suitable for HBV screening in this population. One hundred twenty-three patients belonging to two HD centres from São Paulo, Brazil, were tested prospectively. HBV DNA was detected by polymerase chain reaction (PCR) in each of the prospective subjects $(n=123)$ during one year. Additionally, all samples $(n=1,476)$ were analysed for HBV serological markers. The prevalence of hepatitis B core antibody (anti-HBc), hepatitis B surface antigen (HBsAg) and $H B V$ DNA were $34.1 \%, 15.4 \%$ and $8.1 \%$, respectively, while the incidence was null. Fluctuation in HBV serology was observed in one patient. Only $37.8 \%$ (17/45) of cases responded to the HBV vaccine. Our results suggest that employing more than one HBV marker and repeated follow-up evaluations may improve HBV screening in HD units.

Key words: haemodialysis - hepatitis B - screening

Hepatitis B virus (HBV) infection remains one of the most relevant diseases in humans. Chronic haemodialysis (HD) patients especially are at higher risk for acquiring HBV infection because parenteral exposure is a major route of transmission. In Brazil, there are approximately 65,000 patients who receive HD treatment in 600 dialysis facilities, which include government, nonprofit and profit facilities; $2 / 3$ of them are in hospitals and most of them are in the metropolitan area of São Paulo (SBN 2009). Many recent reports involving Brazilian non-profit public clinics have revealed a high prevalence of HBV. Ferreira et al. (2006) analysed 1,095 HD patients from Goiás and observed that $272(24.8 \%)$ tested positive against anti-hepatitis B core antibody (anti-HBc) and anti-hepatitis B surface antibody (anti-HBs); hepatitis B surface antigen (HBsAg) was also detected in 26 of them (2.4\%). Albuquerque et al. (2009) observed that $29.4 \%$ of patients under HD from five clinics in Recife (Pernambuco, Brazil) tested positive against anti-HBc antibody and HBsAg was detected in $3.3 \%$ of patients. These authors were in agreement that $54 \%$ of patients were either positive for HBsAg, HBV DNA or both. The aim of this study was to determine the prevalence and the incidence of HBV among HD patients and to evaluate whether testing for serological markers at the time of admission is suitable for HBV screening in this population.

Financial support: FAPESP (01/11405-4)

+ Corresponding author: regina.moreira7@gmail.com

Received 7 July 2009

Accepted 1 December 2009
All patients $(n=123)$ undergoing treatment in two HD centres from March 1997-April 1998 were included in this study. The study protocol was submitted and approved by the Ethical Committee of Adolfo Lutz Institute and an informed consent was obtained from each patient. These facilities were considered to be representative of local (São Paulo, Brazil) standard HD services. Both units were comparable in terms of the budget per subject, presence of an isolated area for HBV and HCV patients, recommendation of $\mathrm{HBV}$ vaccination for patients and staff and isolation of HBsAg-positive patients to the last shift of the HBV room. These HD centres had standard conditions as determined by Brazilian competent organs and by the CDC guidelines, including isolation of HBsAg-positive patients in a separate room and assignment of staff members to HBsAg-positive patients, but not to HBV-susceptible patients during the same shift, as well as assignment of a supply tray to each patient (CDC 2001, MS 2004).

HD patients had previously received four doses of $40 \mu \mathrm{g}$ of Engerix ${ }^{\mathrm{TM}} \mathrm{B}$, administered intramuscularly at zero, one, two and six months. Once a year, anti-HBs is quantified and one dose of vaccine is administered, if necessary. Patients had $10 \mathrm{~mL}$ of blood drawn from arterial-venous fistula just before the HD procedure, at the time of admission and on a monthly basis. Therefore, a total of 1,476 serum samples were obtained and separated into the following three aliquots: serological tests, PCR and reconfirmation, if necessary. Samples were stored at $-20^{\circ} \mathrm{C}$ in a separate freezer.

The first and the last samples from each patient were tested for HBV DNA using DNA extraction and nested PCR (core fragment) techniques, as previously described (Kaneko et al. 1989). All 1,476 samples were tested for $\mathrm{HBsAg}$, total anti-HBc and anti-HBs antibodies using commercially available ELISA kits (Hepanostika ${ }^{\mathrm{TM}}$ Uni- 
form Organon Teknika BV, Boxtel, Holland). Patients who did not present any serological markers at the time of admission were referred to receive four doses of the HBV vaccine.

Anti-HBc reactivity was observed in $34.1 \%$ (CI 95\%; 26.2-42.9) of the patients. HBsAg was detected in $15.4 \%$ (CI 95\%; 9.8-22.6) of the patients and HBV DNA was detected in $8.1 \%$ (CI; 4.2-14.01) of this cohort. On the other hand, the incidence of HBV infection was zero, meaning that there were no seroconversions during the studied period. Our findings regarding HBV markers are in accordance with previous reports, despite the lack of a Brazilian National Survey of HBV infection among HD subjects. Souza et al. (2003) observed that $39 \%$ of HD patients from Tocantins, Brazil were positive for anti-HBc, while Albuquerque et al. (2009) reported that $29.4 \%$ were positive for anti-HBc and 3.3\% for HBsAg in the Northeastern Region of Brasil. In the South, the prevalence was reported to be $10 \%$ for $\mathrm{HBsAg}$ and $32.2 \%$ for anti-HBc (Carrilho et al. 2004). Fabrizi et al. (2008c) reported that the prevalence rate of HBsAg detection within dialysis units in developing countries remains between 2-20\%.

The agreement between HBsAg and HBV DNA was about $65 \%$, perhaps due to low viral loads or transient detections, as observed by other authors (Fabrizi et al. 2008c, Tseng et al. 2008). Among the 19 cases that were positive for the surface antigen, the molecular method did not confirm viral infection in nine $(47.3 \%)$ of the cases. Unfortunately, false positive results were observed in three subjects, who were only positive for HBsAg and no other serological markers. In two of these cases, $\mathrm{HBsAg}$ disappeared without anti-HBs seroconversion. Although it was not our goal to study occult HBV infections, there are no observed cases of this type of infection.

One patient with anti-HBc and anti-HBs reactivity manifested fluctuation in HBsAg from negative to positive in the 2nd, 4th and 7th month. HBV surface antigen reactivity has not been shown to be reduced in patients undergoing HD treatment and it remains unclear whether the procedure contributes to viral reduction in parallel (Fabrizi et al. 2008 a, b, Tseng et al. 2008). Our patient, however, proved to present a false positive HBsAg result.

HD professional staff may be aware that the relatively high rates of HBV prevalence and the identification of transient HBsAg constitute a scenario prone to viral transmission. Patients positive for the surface antigen are considered HBV carriers and are grouped together with other similar cases. However, to avoid false positive results, one should confirm this result with another marker and/or with repeated tests. Therefore, it is highly recommended that patients admitted to HD centres be subjected to tests for serological HBsAg plus anti-HBc, which are economically viable and easy to perform.

Forty-five patients were vaccinated after being admitted to this study and 17 (37.8\%) developed immunological response with detectable HBs antibody within 12 months. Although HBV vaccination is mandatory in all dialysis units in Brasil, it is possible that it has not been adequately implemented. According to the literature, seroconversion rates of higher than $60 \%$ in HD outpatients could be expected (Elwell et al. 2003), but our results were below this level. The vaccination may also be followed by a transient HBsAg reactivity in HD subjects (Jansen et al. 1996, Ly et al. 2002). Therefore, it is not recommended to test for HBV markers within the first 28 days.

In conclusion, our findings corroborate that $\mathrm{HBV}$ is prevalent among HD Brasilian patients. As a result, these subjects should be screened more often, using at least two serological markers at an interval of 2-4 months.

\section{REFERENCES}

Albuquerque ACC, Coêlho RCD, Lemos MF, Cruz AMR, Braz SCM, Moreira, RC 2009. Hepatitis B virus infections profile in different hemodialysis units in Recife, Pernambuco, Brazil. Virus Rev Res 14: 1-18.

Carrilho FJ, Moraes CR, Pinho JRR, Mello IMVG, Bertolini DA, Lemos MF, Moreira RC, Bassit L, Cardoso RA, Dos Santos GR, Da Silva LC 2004. Hepatitis B infection in haemodialysis centers from Santa Catarina state, Southern Brazil. Predictive risk factors for infection and molecular epidemiology. BMC Public Health 4: 4-13.

CDC - Centers for Disease Control and Prevention 2001. Recommendations for preventing transmission of infections among chronic hemodialysis patients 2001. MMWR CDC Surveill Summ 50: 1-43.

Elwel RJ, Neumann M, Manley HJ, Carpentier L, Bailie GR 2003. Hepatitis B vaccination: addressing a drug-related problem in hemodialysis outpatients with a collaborative initiative. Nephrol Nurs J30: 310-313.

Fabrizi F, Lunghi G, Alongi G, Aucella F, Barbisoni F, Bisegna S, Corghi E, Faranna P, Mangano S, Romei-Longhena G, Martin P 2008a. Kinetics of hepatitis B load and haemodialysis: a prospective study. J Viral Hepatitis 28: 917-921.

Fabrizi F, Marzano A, Messa P, Martin P, Lampertico P 2008b. Hepatitis $\mathrm{B}$ virus infection in the dialysis population: current perspectives. Int J Artif Organs 31: 386-394.

Fabrizi F, Messa P, Martin P 2008c. Hepatitis B virus infection and the dialysis patient. Semin Dial 21: 440-446.

Ferreira RC, Teles SA, Márcia AD, Tavares VR, Silva SA, Gomes SA, Yoshida CFT, Martins RMB 2006. Hepatitis B virus infection profile in hemodialysis patients in Central Brazil: prevalence, risk factors and genotypes. Mem Inst Oswaldo Cruz 101: 689-692.

Jansen L, Minuk GY, Fast M, Bernstein KN 1996. Vaccine-induced Hepatitis B surface antigen positivity in adult hemodialysis patients: incidental and surveillance data. J Am Soc Nephrol 7: 1228-1234.

Kaneko S, Feinstone SM, Miller RH 1989. Rapid and sensive method for the detection of serum hepatitis B virus DNA using the polymerase chain reaction technique. J Clin Microbiol 27: 1930-1933.

Ly D, Yee Jr HF, Brezina M, Gitnick G, Saab S 2002. Hepatitis B surface antigenemia in chronic hemodialysis patients: effect of hepatitis B immunization. Am J Gastroenterol 97: 138-141.

MS - Ministério da Saúde, Brasil 2004. Resolução - RDC No 154, de 15 de junho de 2004. Available from: www.e-legis.bvs.br/leisref/public.

SBN - Sociedade Brasileira de Nefrologia, Brasil 2009. Proposta para a elaboração de uma regulamentação técnica para os procedimentos dialíticos realizados, fora os serviços de Nefrologia, em pacientes com insuficiência renal aguda ou com insuficiência renal crônica. Available from: http//www.sben.org.br/pdf/proposta diálise.pdf. [accessed 2009 Sep 22).

Souza KP, Luz JA, Teles SA, Carneiro MA, Oliveira LA, Gomes AS, Dias MA, Gomes SA, Yoshida CFT, Martins RMB 2003. Hepatitis $\mathrm{B}$ and $\mathrm{C}$ in the hemodialysis unit of Tocantins, Brazil: serological and molecular profiles. Mem Inst Oswaldo Cruz 98: 599-603.

Tseng GY, Lin HJ, Fang CT, Cheng YT, Huang CH, Tseng GC, Wang PC, Hung TL, Deng YC, Tsai CC, Yang KY 2008. Haemodialysis reduces the viral load in uremic patients with chronic hepatitis B infection. Ren Fail 30: 1000-1005. 